\title{
PARP3 wt Allele
}

National Cancer Institute

\section{Source}

National Cancer Institute. PARP3 wt Allele. NCI Thesaurus. Code C147979.

Human PARP3 wild-type allele is located in the vicinity of 3p21.2 and is approximately $7 \mathrm{~kb}$ in length. This allele, which encodes poly [ADP-ribose] polymerase 3 protein, is involved in the regulation of DNA base excision repair. 